ANDRZEJ OlubińsKI

ORCID 0000-0003-2658-6153

Uniwersytet Warmińsko-Mazurski

w Olsztynie

\title{
O SPOŁECZNO-POLITYCZNYCH ŹRÓDŁACH ZŁEGO STRESU I JEGO EDUKACYJNYCH SKUTKACH
}

AвSTRAct. Olubiński Andrzej, O społeczno-politycznych źródłach złego stresu i jego edukacyjnych skutkach [On Social and Political Sources of Bad Stress and its Educational Effects]. Studia Edukacyjne nr 55, 2019, Poznań 2019, pp. 39-58. Adam Mickiewicz University Press. ISSN 1233-6688. DOI: 10.14746/ se.2019.55.3

The main problem of considerations concerns the relationships and dependencies between selected socio-political factors as stressors and specific reactions to them of selected categories of people and groups, analysed in terms of educational processes. The author is especially interested in the stressful and educational role of human participation in the system of corporate trade as the source of artificially created needs connected with continuous shopping and multiplying material goods.

The second stress factor analysed below is the character of state power exercised by politicians, with the particular role of its distortion towards authoritarian relations.

The final kind of synthetic summary of the above deliberations is an attempt of critical evaluation of the educational role of stress caused by the authoritarian school. And although the discussed stress factors the author attempts to refer to individual behaviours, taking into account, for example, the concepts of human nature, age and institution (e.g. school), the conclusions and findings resulting from these analyses are also more general. Their essence relates to the thesis that regardless of individual behaviours in a stressful situation, generally negative stressors, such as the impact of corporate economy, pathological character of exercising authority or authoritarian school usually shape negative behaviour, including mainly authoritarian personalities.

Key words: corporatism, authoritarianism, stress, education

\section{Wprowadzenie w problematyke}

Niniejszy artykuł jest pokłosiem uczestnictwa w konferencji naukowej, zatytułowanej "Sytuacje stresowe w przestrzeniach życiowych dziecka”, 
która odbyła się na Wydziale Studiów Edukacyjnych UAM 17 października 2018 roku.

Mianem stresu określa się na ogół stan psychiczny jako efekt postrzegania lub doświadczania wyzwań fizycznych lub/i emocjonalnych, które przekraczają nasze zasoby i umiejętności radzenia sobie. Ogólnie można wyróżnić tak zwane stresory, czyli czynniki oraz wymagania zewnętrzne, jak też stres sensu stricto jako przejawy skutków stresorów w organizmie. Stresorami mogą być zarówno czynniki fizyczne (jak np. hałas, temperatura, czy zmęczenie), psychiczne (np. pośpiech, brak czasu itp.), społeczno-kulturowe (np. izolacja, mobbing, wykluczenie, zmiana miejsca zamieszkania, ostracyzm moralny, konieczność dostosowania się do nowych warunków społecznych itp.), jak również cywilizacyjne (mass media, Internet, technologie informatyczne). Najczęściej stres kojarzony jest ze stanem negatywnym organizmu to jest dystresem, rzadziej zaś ze stanem pozytywnym, czyli eustresem ${ }^{1}$.

W istocie do podstawowych źródeł stresu należy poziom oraz treść zaspokojenia określonych potrzeb zgodnie $\mathrm{z}$ hierarchią zaproponowaną przez Maslowa, według którego tym większy stres, im bardziej niezaspokojone zostaną potrzeby w układzie: a) podstawowe (np. życia, pożywienia, mieszkania, ubioru, seksualna itp.); b) bezpieczeństwa (praw, pewności, zdrowia itp.); c) uznania (szacunku, przynależności, miłości itp.); d) samorealizacji (edukacji, rozwoju możliwości, talentu itp.).

Jakkolwiek negatywnych, szczegółowych czynników stresu może być wiele (np. deprywacja, przeciążenie, utrudnienie, poczucie zagrożenia, konflikty wewnętrzne oraz zewnętrzne, choroba, straty), to w istocie poziom ich szkodliwości dla organizmu ma charakter indywidualny. Podobnie jak indywidualny charakter przybierają określone fazy stresu, to jest mobilizacji, rozstrojenia oraz destrukcji, a także określone reakcje na stres, na przykład fizjologiczne (choroby), psychologiczne (poziom napięcia, drażliwości, nerwice, depresje, apatia, załamanie), behawioralne (gniew, agresja, wrogość, zachowania antyspołeczne, przestępcze).

Wyróżnia się również podstawowe obszary występowania sytuacji stresowych, na przykład praca, nauka (szkoła), rodzina, środowisko życia, są-

\footnotetext{
${ }^{1}$ Samo pojęcie "stres” do literatury naukowej wprowadził H. Selye w roku 1956. Uważał on, że są to głównie fizjologiczne reakcje na zewnętrzne oraz głównie awersyjne bodźce. Natomiast K. Lazarus, w połowie lat 60 . oraz pod koniec XX wieku, uzupełnił podejście fizjologiczne o komponent behawioralny oraz emocjonalny, co w praktyce dało początek nazwie "stres psychologiczny", a z czasem dzięki takim m.in. badaczom, jak A. Baum, J.E. Singer, Evans, czy S. Folkman, reakcje fizjologiczne oraz psychologiczne zostały włączone w ogólną teorię modelu stresu środowiskowego. Zob. na ten temat m.in.: R. Lazarus, S. Folkman, Stress, appraisal, and coping, New York 1984; H. Selye, The stress of life, New York 1956; H. Selye, Stres okietznany, przekł. T. Zalewski, Warszawa 1978; P.A. Bell i in., Psychologia środowiskowa, przekł. A. Jurkiewicz, M. Lewicka, A. Skorupka, T. Sosnowski, J. Suchecki, Gdańsk 2004.
} 
siedztwo, przynależność do określonych grup, aktywność społeczna, kulturalna, polityczna, ale również własna psychika (np. system wartości, choroby psychiczne) oraz biologiczna odporność organizmu (zdrowie i choroby, starzenie się itp.).

Zupełnie osobną kwestią związaną z negatywnym stresem jest problem skutków oraz próby radzenia sobie z tego typu sytuacjami. Będzie o tym mowa poniżej, w kontekście $\mathrm{z}$ jednej strony społecznych oraz edukacyjnych źródeł dystresu, a z drugiej w kontekście zastępczych, pozornych, czy wręcz chorobowych form ucieczki („radzenia sobie”) od tego typu negatywnego stresu. W tym miejscu można jedynie wspomnieć, iż oczywiście istnieje cały szereg pozytywnych form radzenia sobie ze stresem; zarówno o charakterze zewnętrznym (wsparcie, psycho- i socjoterapia, farmakologia, zmiana warunków i środowiska życia, hospitalizacja, pomoc materialno-finansowa, zmiana stylu życia itp.), jak i wewnętrznym (edukacja, wzrost kompetencji oraz umiejętności, wzrost świadomości i wiedzy o stresie i jego skutkach, unikanie zbyt dużego stresu itp.).

Ogólne, psychospołeczne oraz biologiczne skutki życia w stresie, w kontekście różnorodnych uwarunkowań, zwłaszcza indywidualnych, są w literaturze przedmiotu dobrze opisane ${ }^{2}$. Do bardziej znanych ich symptomów należą między innymi: zawały, udary, nadciśnienie, wrzody żołądka, nerwice, lęki, depresje, wypalenia, załamanie, apatia, zachowania antyspołeczne czy przestępcze, ale również zachowania agresywne, autorytarne, postawy złości, wrogości, nienawiści, cynizmu, ucieczki w uzależnienia, używki, lęki, apatia, fanatyzm, cyberprzestrzeń i tym podobne.

Sądzę, że z psychospołecznego punktu widzenia, najogólniej rzecz ujmując, można wyróżnić trzy główne czynniki (stresory) będące źródłem różnorodnych napięć, konfliktów, czy zaburzeń funkcjonowania człowieka żyjącego $\mathrm{w}$ tak zwanej ponowoczesnej cywilizacji oraz $\mathrm{w}$ tak zwanym wychowującym społeczeństwie. Są to: 1) ideologia i praktyka neoliberalnej (korporacyjnej) ekonomii; b) ideologia oraz praktyka sprawowania władzy państwowej; 3) autorytarny system edukacji szkolnej. Oczywiście, osobnej uwagi wymagałoby omówienie dalszych stresorów, takich jak na przykład rola cywilizacji technologiczno-informatycznej, środowisko rodzinne, praca, aktywność oraz uczestnictwo w kulturze i tym podobne. Jednocześnie warto zauważyć, że wszystkie tego typu źródła stresu mogą w różnoraki sposób de-

${ }^{2}$ Zob. w tym zakresie np.: J.N., Butcher, J.M., Hooley, S. Mineka, Psychologia zaburzeń, przekł. S. Pikiel, A. Sawicka-Chrapkiewicz, Sopot 1917; I. Heszen, Psychologia stresu, Warszawa 2018; C.M., Wheeler, Pokonaj stres. 10 sprawdzonych metod, Gdańsk 2016. Warte uwagi jest tutaj również opracowanie M. Cywińskiej, Stres dzieci w młodszym wieku szkolnym. Objawy, przyczyny, możliwości przeciwdziałania, Poznań 2018. Jest to oryginalne studium oparte na wynikach badań empirycznych reakcji na stres oraz radzenia sobie z nim przez dzieci w młodszym wieku szkolnym. 
terminować reakcje oraz zachowania człowieka. Oznacza to, że z jednej strony mogą one działać jako czynniki mobilizujące, aktywizujące, pobudzające, czy rozwijające osobowość, ale z drugiej, w odniesieniu do konkretnej sytuacji oraz osób, mogą być źródłem złego stresu czy distresu. I głównie na tych negatywnych sytuacjach oraz procesach poniżej postaram się skupić uwagę.

\section{Problem indywidualnych reakcji na stres w świetle elementarnych koncepcji ludzkiej natury}

Na początek rozważań warto jednak przez chwilę zatrzymać się na zagadnieniu indywidualnej roli oraz edukacyjnych skutków, które wiążą się z zetknięciem się ze stresorami $\mathrm{w}$ aspekcie na przykład koncepcji ludzkiej natury. Wprawdzie dotychczas żadne badania jednoznacznie jeszcze nie dowiodły, jaka jest prawdziwa nasza natura, jednak istnieje $w$ tym zakresie kilka koncepcji - hipotez, na podstawie których można próbować analizować, interpretować oraz wyjaśniać określone zachowania będące reakcją na stresory ${ }^{3}$.

I tak, wydaje się, że biorąc pod uwagę najbardziej ogólne w tym zakresie poglądy, można sądzić, że na przykład inny będzie wpływ stresorów na człowieka, który z natury jest niezapisaną kartą (tabula rasa), inny kiedy przyjmiemy założenie, że człowiek jest w największym stopniu już zapisaną kartą, jeszcze inny gdy zdefiniujemy człowieka jako istotę zdolną do przetwarzania, tudzież selekcjonowania docierających do niego informacji, inny gdy założymy, że w największym stopniu przychodzi on na świat jako istota moralnie dobra. I jakkolwiek obecny stan wiedzy zdaje się sugerować, że na ludzkie zachowania składają się zarówno indywidualne czynniki wrodzone, z którymi przychodzi on na świat, jak i zespół czynników społeczno-kulturowych, które owe wrodzone predyspozycje modyfikują, to niewątpliwie przy obecnym stanie wiedzy wydaje się, że w każdej z wymienionych powyżej koncepcji tkwi jakieś ziarno prawdy, a zatem w jakimś stopniu można również w tym kontekście próbować analizować oraz interpretować indywidualne lub/i społeczne reakcje człowieka na określone czynniki wywołujące stres, a w związku z tym w jakimś stopniu także przewidywać możliwe wynikające z tych reakcji skutki (konsekwencje) dla zmian w ludzkim zachowaniu ${ }^{4}$.

${ }^{3}$ Zob. w tym zakresie m.in.: M.S. Gazzaniga, Istota człowieczeństwa. Co sprawia, że jesteśmy wyjątkowi, Sopot 2011; C.S., Hall, G. Lindzey, Teorie osobowości, Warszawa 1990; J.R., Harris, Geny czy wychowanie ? Co wyrośnie z naszych dzieci i dlaczego, Warszawa 1998; S. Pinker, Tabula rasa. Spory o naturę ludzka, Gdańsk 2005; B. Śliwerski, Wspótczesne teorie i nurty wychowania, Kraków 2004.

${ }^{4}$ Niestety to, że neurobiolodzy oraz psychologowie nie są zgodni co do czynników wpływających na ludzkie zachowanie staje się nierzadko przyczyną dowolnej w tym zakresie in- 
Oczywiście, warto tutaj także dostrzec z jednej strony fakt dużych w tym zakresie indywidualno-emocjonalnych zróżnicowań na podobne lub takie same stresory, a z drugiej - na określony rodzaj, zwłaszcza złych stresorów, które na ogół zawsze wywołują negatywne skutki w kontekście zmian w zachowaniu czy postawach, niezależnie od różnic indywidualnych. Do owych czynników negatywnych można zapewne zaliczyć na przykład sytuacje niezaspokojenia podstawowych oraz rozwojowych potrzeb, a także powszechnie potępiany w danej kulturze, środowisku czy grupie system wartości, poglądów, zachowań oraz postaw.

Ogólnie jednak rzecz biorąc, na przykład kiedy mielibyśmy do czynienia ze zwolennikami poglądu, iż natura jest tabula rasa, a więc gdy człowiek od momentu poczęcia aż do śmierci uczy się oraz przyswaja sobie wszystkie docierające do niego treści ze świata zewnętrznego, uczy się zatem również jakie treści czy bodźce stanowią sytuację zagrożenia lub jakie czynniki stymulują go do podjęcia wysiłku oraz działań, które mogą optymalizować jego rozwój. W tym wypadku to zatem głównie od warunków życia, doświadczeń społeczno-kulturowych, socjalizacji oraz edukacji w dużym stopniu zależy, jakie treści oraz czynniki będą stresorami korzystnymi, a jakie niekorzystnymi dla jego zachowań, a także w jaki sposób na te czynniki reagować. Jeśli zatem na przykład człowiek doświadczył w życiu sytuacji deprywacji określonych potrzeb, to sytuacja taka nie powinna wywoływać u niego większego dy/stresu lub kiedy doświadczył w życiu przemocy, to przemoc nie powinna robić na nim negatywnego wrażenia, pomijając oczywiście fakt różnicy form i poziomu jego w tym zakresie doświadczeń. I odwrotnie, jeśli człowiek żył w dobrobycie, to socjalnomaterialna deprywacja powinna być dla niego źródłem silnego dystresu. Opierając się na tej teorii, behawioralnie analizować można niemal wszystkie obszary ludzkiej osobowości, w relacji do reakcji na stres.

W zasadzie, w podobny sposób można również próbować interpretować koncepcje psychoanalityczne. W tym kontekście mniej lub bardziej stresujące dla jednostki będą te sytuacje, które w mniejszym lub większym stopniu odbiegają od jej wrodzonych cech i predyspozycji. Jeśli więc ktoś z natury jest przestępcą, to jakichś przestępczy stresor nie tylko nie powinien wywoływać u niego negatywnej reakcji stresująco-obronnej, lecz być może sytuacja taka poprawi jego samopoczucie.

O wiele trudniejszą do wyjaśnienia reakcją na stres jest opowiedzenie się za koncepcją poznawczą, według której zachowanie jest funkcją analizy, rozumienia oraz internalizacji treści płynących do człowieka informacji. W tym

terpretacji, np. polityków, kapłanów, szarlatanów, a nawet pedagogów itd., wykorzystujących ten fakt do uzasadniania swoich niekiedy np. rasistowskich, behawioralnych czy autorytarnych poglądów, ideologii oraz postaw. 
kontekście poziom stresu oraz reakcji na stres to także poziom rozwoju poznawczego, ale także treść oraz charakter docierających do człowieka informacji. Zatem, im więcej wiedzy na temat stresorów, tym bardziej wyważona reakcja na stres i tym większe prawdopodobieństwo uniknięcia jego negatywnych skutków. I odwrotnie, niewiedza o źródłach stresu może wiązać się $\mathrm{z}$ negatywnymi formami ucieczki przed nim.

Częściowo optymistyczna wersja relacji pomiędzy koncepcją natury a stresem może wynikać z przyjęcia teorii humanistycznej, według której człowiek przychodzi na świat z natury jako istota dobra, jako wartość moralna (w rozumieniu ogólnoludzkich wartości), którą dopiero psują okoliczności i sytuacje zewnętrzne. $W$ tej koncepcji poziom oraz kierunek reakcji na stres byłby z jednej strony funkcją treści stresorów, według kryteriów: im bardziej odbiegają od wartości dobra, tym bardziej są dla człowieka dy/ stresujące; z drugiej jednak charakter reakcji człowieka na stres zależałby od poziomu jego demoralizacji, a zatem również jego tolerancji wobec negatywnych stresorów.

Jeśli natomiast wyznawalibyśmy pogląd odnoszący się do paralelnej roli czynników wrodzonych oraz środowiskowo-kulturowych, to - zgodnie $\mathrm{z}$ aktualnymi $\mathrm{w}$ tym zakresie ustaleniami - negatywne reakcje na stres byłyby funkcją z jednej strony dobrych genów oraz złych stresorów lub z drugiej - złych genów oraz wartościowych stresorów. Ściślej rzecz biorąc - jak to konstatuje cytowany powyżej S. Pinker - jeśli człowiek wyposażony jest $\mathrm{w}$ większym stopniu $\mathrm{w}$ dobre geny, to negatywne środowisko nie powinno istotnie je wypaczyć. Natomiast, kiedy mielibyśmy do czynienia z przewagą negatywnych genów, to wartościowe warunki oraz sytuacje życia z trudem mogą przebić się przez owe złe geny ${ }^{5}$. Z punktu widzenia koncepcji stresu można w tym kontekście powiedzieć, że w sytuacji wyposażenia w złe geny, wartościowe stresory mogą być źródłem negatywnego stresu, zaś w sytuacji wyposażenia w dobre geny, dystresem będą negatywne uwarunkowania społeczno-środowiskowe.

Wydaje się, że koncepcja poznawcza oraz humanistyczna nie muszą się wykluczać, a w pewnym sensie nawet uzupełniać się. Człowiek może bowiem brać pod uwagę interes własnego dobra oraz optymalnego rozwoju, analizując, selekcjonując oraz przyswajając docierające do niego z zewnątrz informacje. W tym kontekście tylko mądrzy, rozumni ludzie zdolni byliby reagować na sytuacje stresujące albo starając się je ograniczyć lub wyeliminować, albo starając się spożytkować określone ich rodzaje w sposób optymalizujący jego własny rozwój.

\footnotetext{
${ }^{5}$ S. Pinker, Tabula rasa. Spory o naturę ludzka, Gdańsk 2005, s. 530-541.
} 


\section{O stresogennej roli ideologii oraz praktyki korporacyjnej ekonomii}

Niewątpliwie potężnym źródłem (stresorem) stresu dla wielu ludzi zaspokajających swoje codzienne socjalno-ekonomiczne potrzeby jest ideologia, a głównie praktyczna rola, jaką odgrywa w życiu każdego człowieka neoliberalna ekonomia. Należy sądzić, że człowiek żyjący w warunkach zachodniego dobrobytu, w istocie stał się swoiście rozumianą ofiarą edukacji ekonomicznej, której hasłami są między innymi produkowanie, kupowanie, handlowanie, głównie materialnymi dobrami po to, aby mieć, mieć i mieć. Sposób, styl, sens, czy wartość ludzkiego życia sprowadzona została do produkowania oraz nabywania dóbr, do zaspokajania materialnych potrzeb oraz bezpardonowej walki o ich posiadanie. Jeśli zatem taki jest zasadniczy, prawdziwy, choć oczywiście najczęściej ukryty, cel aktywności oraz działalności człowieka, to czy tego typu procesy „zmuszające” ludzi do jego realizacji mogą być źródłem jego stresu? Dla jakich zatem ludzi idea oraz praktyka zmuszająca ich do walki o dobra materialne oraz postaw konsumpcyjnych, zakupoholizmu, będą czynnikami negatywnego stresu przyczyniającego się do obniżania możliwości ich rozwoju?

Aby nieco przybliżyć wersję możliwych odpowiedzi na tak zadane pytanie, przyjrzyjmy się nieco bliżej głównym tezom ideologii oraz już wprowadzanej w życie praktyce edukacji proponowanej przez przedstawicieli korporacyjnej ekonomii. Bardziej szczegółową charakterystykę jej założeń można znaleźć w co najmniej kilku opracowaniach odnośnie tej dziedziny ${ }^{6}$.

Zatem, głównym, choć ukrytym, założeniem neoliberalnej ekonomii jest dążenie do maksymalizacji produkcji dóbr materialnych, systematycznego handlowania nimi, dokonywania ich zakupów oraz ich konsumowania. Upowszechnianie tego założenia w społecznej makroskali w coraz większym stopniu i zakresie staje się swoiście rozumianym nakazem, psychologicznym przymusem oraz jak gdyby obywatelskim i patriotycznym obowiązkiem każdej jednostki tak, że jeśli ktoś nie produkuje, nie kupuje, nie konsumuje oraz w jakikolwiek inny sposób nie przyczynia się do realizacji tych celów, powinien mieć wyrzuty sumienia, powinien mieć świadomość, iż nie przyczynia się do rozwoju społeczno-gospodarczego, powinien starać się tego typu „zaległości" nadrobić. W sumie, powinien więc mieć uczucie zagrożenia, niepew-

${ }^{6}$ Na temat edukacyjnej roli neoliberalnej ekonomii pisali m.in.: E. Potulicka, E. Rutkowiak, Neoliberalne uwikłania edukacji, Kraków 2012; J. Bakan, Korporacja, Patologiczna pogoń za zyskiem i władza, Warszawa 2006; D. Harvey, Neoliberalizm. Historia katastrofy, Warszawa 2008; T. Szkudlarek, Ekonomia i moralność: przemieszczenia dyskursu edukacyjnego, Taraźniejszość - Człowiek - Edukacja, 2001, nr specjalny; Z. Bauman, Szanse etyki w zglobalizowanym świecie, Kraków 2007; N. Chomsky, Zysk ponad ludzi. Neoliberalizm a ład globalny, przekł. M. Zuber, Wrocław 2000. 
ności oraz lęków. W coraz większym stopniu obserwowalny pęd do pracoholizmu oraz zakupoholizmu, jako sztucznie wykreowanych ludzkich potrzeb, to właśnie nowe źródło indywidualnej oraz społecznej choroby związanej z poczuciem niespełnienia (stresu), ale z drugiej - również forma ucieczki lub rozładowania uczuć związanych z tym napięć oraz lęków. Konsumpcyjny styl życia oraz związany z nim nowy system wartości dla większości tak zwanych cywilizowanych społeczeństw stały się nową formą uzależnienia, koniecznym sposobem spędzania czasu, nowym rodzajem codziennej aktywności, bez której po prostu coraz trudniej ludziom żyć. Przy czym, nie chodzi tutaj oczywiście o negowanie potrzeby dokonywania codziennych zakupów, lecz właśnie o fakt, iż nastawienie na konsumpcję stało się zasadniczym sensem oraz celem życia, kolejnym uzależnieniem ze wszystkimi wynikającymi stąd objawami chorobowymi, które w coraz większym stopniu zniewalają ludzką istotę, pozbawiając ją jej ludzkich cech.

Jak bowiem inaczej można określać psychospołeczne skutki uzależnienia od produkowania, kupowania oraz konsumowania, jeśli wśród zasadniczych założeń, tez oraz celów korporacyjnej edukacji spotykamy między innymi takie sformułowania, jak:

a) ogół społeczeństwa należy podzielić na producentów i konsumentów oraz ludzi zbędnych (,śmieci") nie przydatnych na rynku;

b) aktywny oraz godny uwagi człowiek to ten, który potrafi się (lub innych ludzi) dobrze sprzedać na rynku;

c) główną formą dialogu oraz działań powinna być darwinistyczna konkurencja oraz dominacja nad słabszymi, w celu osiągnięcia rynkowych sukcesów;

d) neoliberalny ideał człowieka to głównie: bezrefleksyjny konsument, agresywny konkurent oraz posłuszny niewolnik, wykonujący polecenia biznesu;

e) prawdziwy stan samorealizacji można osiągnąć głównie przez konsumpcję oraz realizację wartości hedonistycznych;

f) każdy system edukacyjny powinien przede wszystkim „produkować” konsumentów - automaty, ze świadomością istnienia oraz „bycia” poprzez robienie zakupów (na zasadzie ,jestem tym co kupuje oraz tym co mam”);

g) prawdziwym oraz właściwym „wychowawcą" powinien być wolny rynek kształtujący egoistów, spryciarzy, ludzi potrafiących osiągnąć rynkowy (biznesowy) sukces oraz etycznie pustych;

h) dobry nauczyciel jako wzór oraz autorytet dla uczniów to głównie aktywny zakupoholik oraz konsument o ambiwalentnej tożsamości, wypalony, zagubiony oraz niekompetentny w rozwiązywaniu spraw psychoedukacyjnych, a jednocześnie potrafiący stwarzać pozory oraz wykazywać się postawą hipokryzji na co dzień; 
i) również uczelnie wyższe powinny być częścią wolnego rynku, kierując się zasadami przedsiębiorczości, rozwijaniem ludzkiego kapitału oraz generowaniem zysków;

j) dobry nauczyciel akademicki, to potrafiący walczyć o osiągnięcie rynkowego sukcesu oraz pieniędzy (np. z grantów).

Zatem, jak wynika z przytoczonych powyżej przykładów preferowanych przez neoliberalnych ideologów tez, ogólnie można by stwierdzić, że $\mathrm{w}$ istocie głównym celem korporacyjnej ekonomii jest dążenie do oplątania społeczeństw sieciami zmuszającymi ludzi do rozwijania potrzeb konsumpcyjnych, ujawniających się w preferencji postaw na "mieć", pomnażających zyski nielicznej grupy ekonomicznych krezusów. Jednak edukacyjną ceną takiej postawy, w warunkach cywilizacji masowej komunikacji oraz masowej kultury, jest kształtowanie zachowań biernych, konformistycznych, antykreatywnych i tym podobnych, ale także agresywnych, wrogich, nastawionych na odniesienie spektakularnych sukcesów, a z drugiej strony - jednostek osamotnionych, przegranych, wykluczonych, z poczuciem krzywdy i tym podobnych, czyniących $\mathrm{w}$ sumie $\mathrm{z}$ ludzi reaktywne automaty o maksymalnie stłumionej osobowości. W istocie zatem, system nakłaniający ludzi do rozwijania oraz zaspokajania nienaturalnych, nieludzkich potrzeb "produkuje" reaktywne automaty, o maksymalnie stłumionej spontaniczności, podmiotowości oraz tożsamości w sposobach wyrażania uczuć oraz emocji.

Wydaje się, że dystresem będzie sytuacja względem ludzi mniej lub źle wyedukowanych, mechanicznie oraz bezpośrednio reagujących na zewnętrzne bodźce, podatnych na manipulację, propagandę, tresurę oraz indoktrynację, jak też w stosunku do tych, którzy charakteryzują się postawami konformistycznymi, hipokryzji, czy hołdujących wartościom materialnym, hedonistycznym bądź autorytarno-dominacyjnym, a z drugiej strony - w stosunku do pozbawionych własnej autonomii, podmiotowości, czy systemu humanistycznych wartości i tym podobnych.

O tresowaniu (lub stresowaniu) określonych kategorii ludzi do reagowania na konsumpcyjno-materialistyczne bodźce pisze wielu filozofów oraz psychologów edukacji. Już niemal pół wieku temu problem ten opisywał między innymi E. Fromm, mówiąc o zjawisku depersonalizacji oraz reifikacji relacji społecznych oraz o tak zwanym „utowarowieniu” osobowości (tj. osobowości rynkowo-marketingowej), którą można dowolnie handlować na rynku pracy, życia towarzyskiego, rozrywki, a nawet przyjaźni czy miłości. Zatem, "ludzkie produkty" konsumpcyjnej edukacji, pozbawione własnej tożsamości, podmiotowości, a także wyzuci z humanistycznej etyki, z jednej strony łatwo ulegają różnego rodzaju manipulacjom, indoktrynacjom ukierunkowanym zwłaszcza na obiecanie zapewnienia im potrzeb materialnych, z drugiej takie ludzkie konsumpcyjne przedmioty same nauczyły się manipu- 
lować oraz „zachęcać” do podobnych zachowań innych ludzi, także w celu osiągnięcia materialnych korzyści własnych ${ }^{7}$.

Ale stresująca, nieustanna pogoń za dobrami materialnymi kształtuje szereg innych postaw, na przykład hipokryzji, zakłamania oraz fałszu, co na przykład w socjalno-edukacyjnej praktyce nierzadko przekłada się na załatwianie egoistycznych interesów pod pozorami pomocy dla innych lub nawet poświęcania się dla innych. W ten sposób podopieczny, uczeń, czy często osoby nominalnie nam bliskie stają się przedmiotami, tudzież środkami, za pomocą których pomnażamy własne dobra, czy załatwiamy własne interesy, po zakończeniu których ów uczeń, kolega, czy "przyjaciel” stają się nam już niepotrzebni. Tego typu coraz bardziej widoczny, choć jeszcze zakamuflowany oraz pozorowany, handel ludźmi dokonywany przez „ludzki towar” staje się elementem procesu edukacji pozbawiających ludzi ich ludzkich właściwości oraz cech. Niestety, zagrożenie tego typu „ekonomiczną" edukacją polega głównie na tym, że większość ludzi nie ma świadomości faktu, że podlegają marketingowej manipulacji, że są niejako zmuszani do reagowania na handlowe bodźce - żyjąc w złudzeniu, że określone w takich sytuacjach ich zachowania czy wybory wynikają z ich wolnej oraz autonomicznej woli.

Ale nieludzkie postawy oraz zachowania, jako efekt reakcji na stres wywołany sztucznie kreowanymi bodźcami, widoczne są również w wielu innych obszarach naszej codziennej egzystencji, na przykład w pracy, uczestnictwie w kulturze, spędzaniu wolnego czasu, rozrywce, czy społecznej komunikacji. Wspólnym mianownikiem uczestnictwa zestresowanych przez uzależnienie od dóbr materialnych ludzi w tych obszarach jest w coraz większym stopniu ich masowość oraz anonimowość, skutkujące między innymi z jednej strony depersonalizacyjno-przedmiotowym charakterem aktywności, a z drugiej co ściśle wiąże się z procesem dezindywiduacji - postawami bierności, gnuśności, antykreatywności, unikania wysiłku, problemów oraz sprzeczności i tym podobnych, co $\mathrm{w}$ dalszej konsekwencji skutkuje bardziej dysfunkcjonalnymi zmianami zachowań, ale także przejawami marginalizacji oraz alienacji życia społecznego, a wreszcie negacją jego sensu.

Całe uczestnictwo w tak zwanej masowej kulturze jako produkcie ponowoczesnej cywilizacji oraz konsumpcyjnego stylu życia, których istota sprowadza się do taniej rozrywki, "tworzenia” blichtru, tandety, szmiry oraz "sztuki” prymitywnej, przyciągających coraz większą liczbę fanów (np. muzyki disco polo), skonstruowanych według tych samych standardów (sche-

${ }^{7}$ Zob. m.in. w tym zakresie takie prace E. Fromma, jak: Mieć czy być. Duchowe podstawy nowego społeczeństwa, przekł. J. Karłowski, Poznań 1983; Anatomia ludzkiej destruktywności, przekł. J. Karłowski, Poznań 1998; Niech się stanie człowiek. Z psychologii etyki, przekł. R. Saciuk, Warszawa - Wrocław 1994; Ucieczka od wolności, przekł. R. Saciuk, Warszawa - Wrocław 1987. 
matów), wzorów czy norm - w istocie są też stresogenne, bo zabijają także wszelkie odruchy indywidualne, niepowtarzalne; wszelkie reakcje, emocje oraz postawy autentycznie twórcze, zmuszając do zachowań schematycznych, rutynowych, powtarzalnych - czyniąc z ludzi „przedmioty - narzędzia - roboty" reagujące na zewnętrzne dzwonki.

W sumie, człowiek skupiony na walce o posiadanie dóbr, na agresywnym wdrapywaniu się po karierę oraz sukces czy na biernym i hedonistycznym uczestnictwie $\mathrm{w}$ kulturze, nieświadomie staje się coraz bardziej zniewalany zewnętrznymi mechanizmami społecznej manipulacji oraz indoktrynacji. Liderzy oraz specjaliści od organizacji przemysłu masowej konsumpcji prześcigają się w reklamowaniu swoich produktów, w różnorodny sposób przekonując klientów do potrzeby ich posiadania oraz używania jako przedmiotów niezbędnych do codziennego życia, kosztem deprywacji innych potrzeb rzeczywistych. W tym kontekście J. de Graff, D. Wann oraz T.H. Teylor pisząc o rozszerzającej się epidemii konsumpcji, wprowadzili do obiegu pojęcie „affluenza”, jako swoiście rozumianej nowej odmianie choroby, której widocznymi objawami są między innymi również objawy czysto medyczne, takie jak: gorączka, niestrawność, osłabienie, wymioty, a nawet zmiany skórne ${ }^{8}$.

Ostatecznie więc, wbrew pozorom szczęśliwego życia w społeczeństwie konsumpcyjno-materialnego dobrobytu oraz uczestnictwa w masowej kulturze - jak dostrzega to już wielu filozofów edukacji ${ }^{9}$ - współczesny człowiek jako swoiście rozumiany towar handlowej rynkowej wymiany oraz produkt neoliberalnej edukacji, siłą wyrwany z naturalnego świata ludzi wolnych, podmiotowych oraz kreatywnych: w istocie jest głęboko nieszczęśliwy, żyje w rozpaczy, poszukując prawdziwie ludzkiego szczęścia, prawdziwie ludzkich wartości, zaspokojenia prawdziwie ludzkich potrzeb jako elementarnych warunków dla możliwości optymalnego rozwoju oraz samorealizacji.

W tym kontekście, biorąc pod uwagę określone poglądy na temat ludzkiej natury, można by powiedzieć, że poziom negatywnego stresu wywołanego przez przymus kupowania byłby tym relatywnie większy, im mniej ludzie posiadaliby wiedzy oraz umiejętności obrony przed szkodliwością tego typu postaw, a z drugiej strony stres tym mniejszy, im większa kulturowo-edukacyjna wiedza na temat skutków zakupoholizmu, co oczywiście nie pomniejsza poziomu realnych, osobowych strat związanych z praktyką konsumpcyjnego stylu życia.

${ }^{8}$ Zob. na ten temat: J. dr Graf, D. Wan, T.H. Taylor, The Consuming Epidemic, San Francisco 2001; cyt. za M. Czerepaniak-Walczak, Pedagogika emancypacyjna. Rozwój świadomości krytycznej człowieka, Gdańsk 2006, s. 34.

9 Zob. np. E. Prom, Z. Bauman, P. Bourdieu, C. Rogers i inni. 


\section{O psychospołecznych mechanizmach oraz skutkach patologii sprawowania władzy}

Obok stresogennych sytuacji wywołanych uzależnieniem od konsumpcyjnego stylu życia oraz wynikających stąd konsekwencji dla kształtowania określonych zachowań, postaw oraz systemu wartości, wydaje się, że niemniej istotną $\mathrm{w}$ tym zakresie rolę odgrywa sposób sprawowanej władzy państwowej, zwłaszcza związany z praktyką realizacji ideologii autorytarnego systemu społeczno-ustrojowego. $W$ tym wypadku poziom stresu byłby funkcją wiedzy, doświadczeń oraz treningu (socjalizacji) osób oraz grup żyjących w autorytarnym systemie. Można by tutaj analizować różne warianty ludzkich doświadczeń $\mathrm{w}$ tym zakresie. Zapewne w stosunku do osób ceniących sobie wolność oraz wartość systemu demokratycznego, zetknięcie się z autorytarną władzą byłoby sytuacją wywołującą negatywny stres, natomiast dla osobowości zamkniętych, konformistycznych, czy autorytarnych, tego typu rządy mogłyby być źródłem przeżyć pozytywnych czy oczekiwanych, choć oczywiście tego typu eustres mógłby pogłębiać ich sadomasochistyczne postawy. Wydaje się jednak, że w obu przypadkach stres wywołany patologią sprawowania władzy na ogół zawsze wywołuje negatywne skutki edukacyjne.

Jakkolwiek bowiem sama instytucja władzy państwowej, której celem jest wprowadzanie $\mathrm{w}$ życie przyjętej ideologii społeczno-ustrojowej jest niemal tak stara jak ludzkość, to jednocześnie niemal również od początku istnienia państwa można w jego funkcjonowaniu zaobserwować różnorodne nadużycia, wypaczenia, jak i patologie. Niektórzy autorzy sądzą, że nieprawidłowości te wynikają jak gdyby zarówno z faktu istnienia niesymetrycznych relacji pomiędzy posiadającymi władzę a tymi, którzy jej podlegają, jak również a może przede wszystkim - $\mathrm{z}$ faktu, iż grupy będące u władzy są nominalnie dysponentami określonych dóbr materialno-finansowych, którymi mogą zarządzać poprzez wpływ na stanowienie systemu prawnego, na straży którego stoi posłuszny im aparat przemocy, wobec którego pozostali obywatele mają obowiązek być posłusznymi ${ }^{10}$.

A zatem, głównie z faktu, że istotą wszelkiej władzy jest dysponowanie możliwością wywierania intencjonalnego wpływu na bieg zdarzeń, przebieg różnorodnych zjawisk i procesów społeczno-ekonomicznych, a także na zachowania i działania ludzi w celu podporządkowania ich określonej ideologii oraz określonym celom wynikają nieprawidłowości w jej sprawowaniu ${ }^{11}$. Sta-

${ }^{10}$ Zob. w tym zakresie np. opracowanie B. Nowotarskiego, Erozja młodych demokracji. Odpowiedzialność władzy, Warszawa 2016.

${ }^{11}$ Zob. J. Borkowski, Człowiek zagrożony i niebezpieczny. Socjologia i psychologia zagrożeń, Warszawa 2011, s. 154-164. Por. A. Podgórecki, Patologia życia społecznego, Warszawa 1969; M. Jarosz, 
nisław Ossowski podkreśla zatem ów emotywny charakter władzy, polegający na doświadczaniu przez podmiot władzy uczucia prawa do decydowania o zachowaniu podmiotu podległego, który doświadcza uczucia obowiązku posłuszeństwa ${ }^{12}$. Władza bowiem dysponuje środkami wywierania wpływu społecznego, włącznie z możliwością stosowania zorganizowanej przemocy. Najbardziej wymowną i skuteczną formą władzy praktykującej przemoc jest państwo uprawnione do wymuszania woli władzy.

Przemoc jako forma sprawowania władzy jak gdyby z natury rzeczy zawsze ma mniej lub bardziej charakter patologiczny, bowiem wiąże się z sytuacjami stwarzającymi zagrożenie dla porządku społeczno-politycznego, zarówno w mikro jak i makrostrukturze. Dotyczyć to może na przykład negacji lub lekceważenia przez władzę akceptowanych wartości społeczno-obywatelskich; łamania norm życia publicznego, w tym zwłaszcza norm prawnych, co uznać właśnie można za wskaźnik niedemokratycznej formy ładu ustrojowego (np. niby-demokracji, demokracji fasadowej, czy wręcz państwa autorytarnego) oraz dysproporcji pomiędzy interesami władzy a interesami obywateli. Przy czym, poziom tego typu rozbieżności zależy od wprowadzonego sytemu społeczno-ustrojowego. Im bowiem system bardziej autorytarny, tym tego rodzaju dysproporcje są większe ${ }^{13}$.

Wśród negatywnych następstw szeroko rozumianej patologii sprawowania władzy jako źródła dyskomfortu, niezadowolenia, frustracji oraz stresu, można wymienić na przykład spadek zaufania społecznego wobec władzy, spadek poparcia opinii publicznej, frekwencji wyborczej, rozluźnienie więzi społecznych między władzą a społeczeństwem, funkcjonowanie oraz rozwój antywzorów postaw obywatelskich, naruszających prawno-kulturowy porządek społeczny, mających przyzwolenie lub wręcz leżących w interesie władzy.

Z patologią władzy mamy zatem głównie do czynienia w sytuacji, kiedy państwo $\mathrm{w}$ praktyce realizuje cele sprzeczne $\mathrm{z}$ elementarnymi wartościami oraz normami demokracji, niezależnie od deklarowanych $w$ tym zakresie celów i funkcji. Nie oznacza to zatem, że patologie nie występują również w państwie demokratycznym, zwłaszcza na etapie przechodzenia od autorytaryzmu do demokracji. Młode państwo demokratyczne cechuje bowiem na ogół: brak odpowiednich kompetencji w sprawowaniu władzy; brak dojrzałości indywidualnej oraz instytucjonalnej; partykularyzm oraz konflikt

Wtadza, przywileje, korupcja, Warszawa 2004; J. Koralewicz, Autorytaryzm, lęk, konformizm. Analiza społeczeństwa polskiego końca lat siedemdziesiatych, Wrocław 1987; Wtadza. Pokusy i zagrożenia, red. A.Y. Lee-Chai, J.A. Bargh, Gdańsk, 2009.

12 S. Ossowski, Dzieła, t. 5 - Z zagadnień struktury społecznej, Warszawa 1968.

${ }^{13}$ J. Borkowski, Człowiek zagrożony i niebezpieczny. Socjologia i psychologia zagrożen, Warszawa 2011, s. 156. 
interesów różnych ugrupowań; rutynizacja i fasadowość funkcjonowania; klientelizm polityczny i ekonomiczny; nieuporządkowany charakter życia publicznego i tym podobne. $Z$ różnorodnymi przykładami patologii funkcjonowania władzy mieliśmy oraz mamy do czynienia także w naszym kraju po roku $1989^{14}$.

Tak czy inaczej, wszelkie uchybienia, nieprawidłowości oraz patologie związane $\mathrm{z}$ kierowaniem państwem, w różnoraki sposób oraz $\mathrm{w}$ odniesieniu do różnych grup społecznych, są zarówno źródłem ich frustracji, lęków, niepewności oraz stresu, jak i często wprost skutkują wieloma dysfunkcjami oraz zaburzeniami czy to $\mathrm{w}$ działalności określonych instytucji, czy wprost $\mathrm{w}$ zachowaniach i postawach obywateli. Przykładów w tym zakresie jest niestety sporo, gdyby powołać się choćby na błędy sprawowania władzy $\mathrm{z}$ ostatnich kilku lat w naszym kraju. Jak bowiem frustrująca może być sytuacja, kiedy coraz bardziej widoczne są takie zjawiska w obozie władzy, jak: nepotyzm, niekompetencja ministrów oraz urzędników, ewidentna krytyka lub wręcz niszczenie opozycji, ograniczanie działalności lub próby likwidacji niezależnych sądów, samorządów oraz grup i osób krytykujących władzę, próby ingerencji w twórczą działalność artystyczną oraz aktywność kulturalną, jak widoczna propagandowa indoktrynacja, manipulacja oraz dezinformacja uprawiana $\mathrm{w}$ podległych władzy środkach masowej komunikacji, jak tolerowanie hipokryzji, kłamstwa, agresji, nienawiści, szowinistycznego nacjonalizmu, coraz bardziej widocznych postaw chamstwa, destrukcji, fanatyzmu, jak ograniczanie wolności do krytyki i twórczości, do preferowanego systemu wartości i tym podobne. Negatywne postawy na tego typu patologiczne zachowania władzy mogą być różne: począwszy od hipokryzji, zakłamania, konformizmu, klientelizmu, uległości, poprzez poczucie beznadziejności, bezsensu, autoizolacji, bierności, bezczynności, aż do postaw wrogości, agresji, nienawiści, przemocy, chamstwa, arogancji, czy szowinizmu. Przy czym, wydaje się, że stresogenna rola patologii sprawowania władzy jest tym większa, im większy poziom edukacji określonych grup społecznych, im większa internalizacja wolnościowo-demokratycznych wartości, czy im wyższy poziom podmiotowo-twórczego rozwoju. Natomiast większej tolerancji (a zatem również mniejszego stresu) wobec wypaczeń sprawowania władzy należałoby się spodziewać w odniesieniu do grup, które jeszcze nie doświadczyły prorozwojowej roli wolności, które nastawione są na zaspokajanie głównie materialnych potrzeb lub/i których osobowość „z natury” tudzież „dzięki” edukacji ma charakter zamknięty, konformistyczny, a głównie autorytarny ${ }^{15}$.

${ }^{14}$ Tamże, s. 171-172.

${ }^{15} \mathrm{Na}$ temat edukacyjnej roli sprawowania władzy państwowej, zob. m.in. A. Olubiński, Edukacja jako sprawowanie władzy, Wychowanie na co Dzień, 2010, 4. 


\section{O stresogennej roli autorytarnej edukacji ucznia w szkole}

Wydaje się zatem, że system kierowania państwem i społeczeństwem noszący znamiona władzy autorytarno-totalitarnej zawsze dla określonych jednostek oraz grup jest czynnikiem frustracyjno-stresującym, w związku z czym przyczynia się do ujawniania różnorakich zachowań „chorobowych", to znaczy takich, które hamują lub blokują optymalny, podmiotowy i twórczy indywidualny rozwój, a także stanowią barierę dla realizacji pożądanych celów społeczno-ekonomicznych. Niedemokratyczne państwo oraz ściśle z nim związane nieprawidłowości (a często wręcz patologie) sprawowania władzy przenikają do poszczególnych podsystemów społecznych (np. instytucji edukacyjno-gospodarczych), hamując ich rozwój, ale głównie "produkując” chore osobowości, relacje społeczne, systemy wartości, czy postawy i zachowania ludzi.

Oczywiście, autorytarny lub/i antydemokratyczny system sprawowania władzy zawsze dociera również do instytucji stricte edukacyjnych (szkół, placówek opiekuńczo-wychowawczych, ośrodków reedukacyjnych itp.), stanowiąc tutaj podstawę dla realizacji podobnych celów oraz funkcji dydaktyczno-wychowawczych. Zasadniczym bowiem celem funkcjonujących instytucji wychowawczych $\mathrm{w}$ autorytarnym państwie jest mechaniczna adaptacja do zastanych warunków społecznych oraz przepisanych przez system ról, których celem jest ukształtowanie określonego charakteru społecznego (osobowości społecznej) dostosowanego do upowszechnianych przez system wzorów. Jeśli zatem system de facto w praktyce preferuje autorytarny model relacji, zachowań oraz osobowości, to również wszelkie tradycyjne procesy, zjawiska oraz role, takie jak na przykład przyjaźn, miłość, tolerancja, rozwój, sukces, pomoc i tym podobne będą dostosowane, interpretowane czy rozumiane w kontekście relacji, osobowości, czy zachowań autorytarnych. Na przykład, miłość może oznaczać tutaj wykorzystywanie, uprzedmiotawianie czy eksploatację drugiej osoby; pomoc może wiązać się z postawą litości, opłacalności, czy osobistych korzyści w kontaktach pomocowych; rola ojca może polegać na tresurze dziecka poprzez stosowanie głównie kar, zaś tolerancja to głównie szereg dominacyjno-woluntarystycznych decyzji na takie czy inne zachowania podległych mi osób. Aby zatem adekwatnie zidentyfikować znaczenie oraz rolę na przykład tradycyjnych pojęć pedagogicznych używanych w praktyce funkcjonowania określonego systemu społeczno-politycznego, konieczna jest procedura ich empiryczno-kontekstowej weryfikacji. W niedemokratycznym systemie społecznym główną cechą stosunków wychowawczych jest bowiem przede wszystkim dążenie do dominacji nad wychowankami, do podporządkowa- 
nia ich zachowań oraz ukształtowania uległej i adaptacyjno-konformistycznej osobowości ${ }^{16}$.

Jednocześnie, na przykład Erich Fromm wyróżnia trzy główne rodzaje dominacji (sadyzmu) wychowawcy nad wychowankiem, to jest: 1) uzależnienie od pedagoga, na zasadzie pozbawienia podopiecznych ich podmiotowości, tożsamości oraz indywidualności; 2) pragnienia maksymalnej eksploatacji, sadystycznej tresury poszczególnych predyspozycji lub wybranych obszarów osobowości; 3) sadystycznej chęci zadawania bólu oraz cierpień $\mathrm{w}$ procesie dydaktyczno-wychowawczym. W sumie, autorytarne wychowanie polega na próbie całkowitego podporządkowania wychowanka określonym wymogom systemu oraz na całkowitym pozbawieniu go podmiotowych (ludzkich) cech $^{17}$.

Oczywiście należałoby tutaj dodać, że w praktyce autorytarne wychowanie często występuje $\mathrm{w}$ formie ukrytej oraz $\mathrm{w}$ wielu wypadkach nieświadomej (częściowo świadomej). Na przykład, pod postacią nadmiernego zainteresowania dzieckiem czy uczniem; nadmiernej kontroli wszystkich obszarów jego życiowej aktywności; maksymalnej (nadmiernej) dobroci na zasadzie wyręczania go w najprostszych czynnościach jako formie ubezwłasnowolnienia; nadmiernej (np. toksycznej) miłości jako ingerencji w indywidualny świat uczuć, aby panować nad emocjami wychowanka i tym podobne. Celem tego typu, w sumie sadystycznych, zabiegów wychowawczych jest pozbawienie podopiecznego jego prawa do wolności, niezależności, samodzielności, podmiotowości, autonomii, odpowiedzialności oraz tożsamości, a z drugiej strony uzależnienie go od bodźców zewnętrznych, wszelkich zewnętrznych zakazów, nakazów, czy decyzji innych osób. Chodzi tutaj więc o wyprodukowanie osobników zewnątrzsterownych, dobrze w literaturze opisanych ${ }^{18}$.

Tak zatem edukacyjnym celem autorytarnego państwa, ale również - jak była o tym mowa powyżej - korporacyjnej ekonomii jest wyprodukowanie niesamodzielnej oraz podporządkowanej i adaptacyjnej osobowości. Realizacji tego celu ma także między innymi służyć całkowicie podporządkowane państwu publiczne szkolnictwo, które ma w odpowiednio zakamuflowany sposób tłumić indywidualną sferę uczuć, spłycać oraz schematyzować rozwój poznawczy, ale także w swoisty sposób „zabijać” indywidualne akty woli oraz autentyczne pragnienia. Może właśnie dlatego coraz więcej dzieci i młodzieży traktuje autorytarnie działającą szkołę jako instytucję "obcą", jako

${ }^{16} \mathrm{Na}$ temat istoty pedagogiki autorytarnej piszą m.in.: K. Kosiorek, Pedagogika autorytarna. Geneza, modele, przemiany, Kraków 2007; B. Śliwerski, Diagnoza uspołecznienia publicznego szkolnictwa III RP. W gorsecie centralizmu, Kraków 2013; tenże, Meblowanie szkolnej demokracji, Warszawa 2017.

17 Zob. A. Olubiński, E. Fromma koncepcja życia po ludzku, Toruń 1994, s. 71-74.

${ }^{18}$ Na temat tzw. osobowości zewnątrzsterownej zob. opracowanie: D. Riesman, N. Glazer, R. Denney, Samotny tłum, Warszawa 1996. 
placówkę, która kojarzy im się bardziej z zakładem poprawczym lub nawet więzieniem, w których doznają uczucia lęku, strachu, upokorzenia, poniżenia, ośmieszenia czy marginalizacji, niż środowiska, w którym mogliby się twórczo i podmiotowo samorealizować.

Wielu współczesnych filozofów edukacji oraz pedagogów uważa, że w ogóle cechą współczesnej kultury i edukacji - także w społeczeństwach nominalnie lub quasi-demokratycznych - jest to, że zastępuje naturalne zachowania oraz naturalne reakcje emocjonalne wzorami cudzymi, zewnętrznymi, modnymi, czy preferowanymi przez mass media. Do tego politycznocywilizacyjnego trendu ma właśnie dostosować się szkoła, której zadaniem jest blokowanie lub wręcz eliminowanie autentycznych ludzkich uczuć, na przykład poprzez zakaz okazywania czy to niechęci, buntu bądź niezgody jako naturalnego wewnętrznego konfliktu oraz temperamentu. Dziecko czy wychowanek w szkole musi rezygnować $\mathrm{z}$ ujawniania swoich prawdziwych uczuć na rzecz uczuć wyuczonych lub takich, które ujawniać wypada w danej sytuacji czy kontekście (czyli pseudouczuć). Sądzić należy, że taki stan tłamszenia prawdziwych emocji na rzecz emocji wyuczonych (sztucznych) jest zapewne źródłem psychicznego dyskomfortu, czy wręcz distresu ucznia.

W podobnie przedmiotowy sposób zubaża się oraz instrumentalizuje rozwój poznawczy ucznia. Współczesna, opanowana przez biznes oraz polityków szkoła, systemowo spłyca myślenie oraz rozumienie rzeczywistości. Od początku swojej edukacji dziecko, uczeń zniechęcane jest do samodzielnego, a zwłaszcza krytycznego myślenia, na rzecz myśli gotowych, "podanych", cudzych, "lepszych”. Uczeń uczy się głównie wiedzy już wyselekcjonowanej, ułożonej w formie gotowych formułek, ale również podzielonej na przedmioty (atomistycznej), fragmenty oraz przeładowanej tysiącami faktów do zapamiętania. Nie ma tutaj miejsca na samodzielne poszukiwanie prawdy, analizę oraz interpretację faktów, a zwłaszcza własną ich ocenę. W edukacji dominuje podejście scjentystyczne, obiektywistyczne, czysto empiryczne, jak gdyby uczeń był robotem stojącym poza otaczającą go rzeczywistością oraz z nią zupełnie emocjonalnie nie związany. Korporacyjni oraz upolitycznieni pedagodzy próbują oddzielić poznanie oraz rozwój umysłowy zarówno od wewnętrznych przeżyć, subiektywnych wrażeń, czy fenomenologicznej prawdy, jak i od powiązanego z nim indywidualnego świata wartości. $\mathrm{W}$ ten sposób podopieczny jawi się jako istota sztuczna, wewnętrznie nieprawdziwa, uzależniona od zewnętrznej „prawdy obiektywnej” oraz tak zwanych autorytetów, którą cechuje wyuczona bezradność w myśleniu i działaniu.

Należałoby przy tej okazji również dodać, że scjentystyczna oraz fragmentaryczna i powierzchowna metoda rozwoju poznawczego, oddzielona od prawdziwych ludzkich uczuć i moralności, może prowadzić - i jak pokazują to przykłady historyczne - często prowadzi do postaw "inteligentnego", 
a $\mathrm{w}$ istocie fanatycznego niszczenia czy destrukcji, na polecenie czy rozkaz ze strony zewnętrznych autorytetów, "zabija” także indywidualne akty woli oraz związane z nimi autentyczne ludzkie pragnienia. Wielu ludziom po prostu wydaje się, że wiedzą czego chcą, pragną, jakie mają potrzeby, do czego dążą i tym podobne, gdy tymczasem tak naprawdę żyją często $\mathrm{w}$ złudzeniu tych pragnień, $\mathrm{w}$ fałszywym przekonaniu dążenia do zaspokojenia określonych potrzeb, bowiem w rzeczywistości chcą oni jedynie tego, czego się od nich wymaga, do czego są ukierunkowywani, manipulowani, indoktrynowani, przekonywani przez mass media, billboardy, propagandę, innych - podobnych do nich ludzi. Pozytywne reagowanie na te sztucznie kreowane potrzeby daje im (pozorne) poczucie bezpieczeństwa, spokoju, stabilizacji i tym podobne. $W$ istocie, prawdziwą ceną za to jest jednak utrata indywidualnej autentyczności wyrażania własnych pragnień, emocjonalna martwota, fasadowe szczęście, a są zachowania cudze, zautomatyzowane, na rozkaz, czy zewnętrzny bodziec ${ }^{19}$.

\section{Zakończenie}

W sumie należy sądzić, że zarówno edukacyjna praktyka korporacyjnej ekonomii, niedemokratycznie sprawowana władza, zwłaszcza w wersji systemu autorytarno-dyktatorskiego, jak i zmuszona do powielania tego typu wzorów współczesna szkoła, wydają się być w stosunku do wielu grup społecznych czynnikami złego stresu. Z kolei w ten sposób wywołany stan dystresu - jak była o tym mowa powyżej - staje się źródłem kształtowania negatywnych zachowań, negatywnych postaw, a w sumie „nowego człowieka": konsumenta, konformistę, oportunistę, serwilistę, hipokrytę, fanatyka, ignoranta i dyletanta, a przede wszystkim osobnika o postawie autorytarnej, pod maską którego w istocie kryje się człowiek: słaby, „mały”, zniewolony, bezsilny, bezwolny, zakompleksiony, z poczuciem winy i niższości, zagubiony, zdezorientowany, osamotniony, pozbawiony prawdziwie ludzkich, autentycznych cech, bez własnej tożsamości, autonomii, podmiotowości i niezależności. To właśnie owe poczucie bezsilności, znikomości oraz niższości, jako między innymi skutek niezaspokojonych potrzeb oraz życia w warunkach distresu, skłania często ludzi do takich kompensacyjnych zachowań, jak: bezwzględność, destrukcja, agresja, władczość, nietolerancja, czy dominacja, aby choć w ten sposób zostać dostrzeżonym, zachować namiastkę relacji i komunikacji, mieć wpływ na bieg zdarzeń, coś znaczyć. Tak naprawdę bowiem

${ }^{19} \mathrm{Na}$ temat szkoły jako instytucji autorytarnej oraz fasadowo-konformistycznej zob. A. Olubiński, Aktywność i dziatanie jako forma edukacji do samorealizacji czy zniewolenia? W świetle założeń edukacji humanistycznej i krytyczno-emancypacyjnej, Kraków 2018, s. 149-183. 
autorytarna filozofia oraz postawy wynikające ze skrajnej depresji, poczucia pustki oraz osamotnienia i tym podobnych prowadzą do nihilizmu, nienawiści, destrukcji i agresji. Tego typu edukacyjny „sukces” autorytarnej władzy, dominacyjnej edukacji oraz filozofii i praktyki neoliberalno-konsumpcyjnej ekonomii, w istocie jest - zarówno w wymiarze psychoemocjonalnym, między innymi z powodu coraz większej liczby czynników stresogennych, jak i w wymiarze społecznym oraz humanistycznym - ewidentną porażką, stratą ludzkiego potencjału, blokadą dla ludzkiego rozwoju i tym podobnych, które odbudowywać będzie zapewne wiele, wiele następnych pokoleń.

\section{BIBLIOGRAFIA}

Bakan J., Korporacja. Patologiczna pogoń za zyskiem i władza, Wydawnictwo Lepszy Świat, Warszawa 2006.

Bauman Z., Szanse etyki w zglobalizowanym świecie, Wydawnictwo Znak, Kraków 2007.

Bell P.A., Greene Th.C., Fisher J.D., Baum A., Psychologia środowiskowa, przekł. A. Jurkiewicz, M. Lewicka, A. Skorupka, T. Sosnowski, J. Suchecki, Gdańskie Wydawnictwo Psychologiczne, Gdańsk 2004.

Borkowski J., Człowiek zagrożony i niebezpieczny. Socjologia i psychologia zagrożen, Dom Wydawniczy ELIPSA, Warszawa 2011.

Butcher J.N., Hooley J.M., Mineka S., Psychologia zaburzeń, przekł. S. Pikiel, A. Sawicka-Chrapkiewicz, Gdańskie Wydawnictwo Psychologiczne, Sopot 1971.

Chomsky N., Zysk ponad ludzi. Neoliberalizm a ład globalny, przekł. M. Zuber, Wydawnictwo Dolnośląskie, Wrocław 2000.

Cywińska M., Stres dzieci w młodszym wieku szkolnym. Objawy, przyczyny, możliwości przeciwdziałania, Wydawnictwo Naukowe UAM, Poznań 2017.

Czerepaniak-Walczak M., Pedagogika emancypacyjna. Rozwój świadomości krytycznej człowieka, Gdańskie Wydawnictwo Psychologiczne, Gdańsk 2006.

Fromm E., Ucieczka od wolności, przekł. A. i O. Ziemilscy, Czytelnik, Warszawa - Wrocław 1993.

Fromm E., Niech się stanie człowiek. Z psychologii etyki, przekł. R. Saciuk, Wydawnictwo Naukowe PWN, Warszawa - Wrocław 1994.

Fromm E., Mieć czy być. Duchowe podstawy nowego społeczeństwa, przekł. J. Karłowski, Dom Wydawniczy Rebis, Poznań 1995.

Fromm E., Anatomia ludzkiej destruktywności, przekł. J. Karłowski, Dom Wydawniczy Rebis, Poznań 1998.

Gazzaniga M.S., Istota człowieczeństwa. Co sprawia, że jesteśmy wyjątkowi, Wydawnictwo Smak Słowa, Sopot 2011.

Harris J.R., Geny czy wychowanie? Co wyrośnie z naszych dzieci i dlaczego, Jacek Santorski Wydawnictwo, Warszawa 1998.

Harvey D., Neoliberalizm. Historia katastrofy, Instytut Wydawniczy Książka i Prasa, Warszawa 2008.

Heszen I., Psychologia stresu. Korzystne i niekorzystne skutki stresu życiowego, Wydawnictwo Naukowe PWN, Warszawa 2013.

Jarosz M., Wtadza, przywileje, korupcja, Wydawnictwo Naukowe PWN, Warszawa 2004. 
Koralewicz J., Autorytaryzm, lęk, konformizm. Analiza społeczeństwa polskiego końca lat siedemdziesiatych, Ossolineum, Wrocław 1987.

Kosiorek K., Pedagogika autorytarna. Geneza, modele, przemiany, Oficyna Wydawnicza Impuls, Kraków 2007.

Lazarus R.S., Folkman S., Stress, appraisal, and coping, Springer Publishing Co., New York 1984.

Nowotarski B., Erozja młodych demokracji. Odpowiedzialność władzy, Wydawnictwo Sejmowe, Warszawa 2016.

Olubiński A., Ericha Fromma koncepcja życia po ludzku, Wydawnictwo Uniwersytetu Mikołaja Kopernika, Toruń 1994.

Olubiński A., Edukacja jako sprawowanie władzy, Wychowanie na co Dzień, 2010, 4.

Olubiński A., Aktywność i działanie jako forma edukacji do samorealizacji czy zniewolenia? W świetle założeń edukacji humanistycznej i krytyczno-emancypacyjnej, Oficyna Wydawnicza Impuls, Kraków 2018.

Ossowski S., Dzieła, t. 5 - Z zagadnień struktury społecznej, PWN, Warszawa 1968.

Pinker S., Tabula rasa. Spory o nature ludzką, Gdańskie Wydawnictwo Psychologiczne, Gdańsk 2005.

Podgórecki A., Patologia życia społecznego, PWN, Warszawa 1969.

Potulicka E., Rutkowiak E., Neoliberalne uwikłania edukacji, Oficyna Wydawnicza Impuls, Kraków 2012.

Riesman D., Glazer N., Denney R., Samotny tłum, Wolters Kluwer, Warszawa 1996.

Selye H., The stress of life, McGraw-Hill, New York 1956.

Selye H., Stres okietznany, przekł. T. Zalewski, PIW, Warszawa 1977.

Szkudlarek T., Ekonomia i moralność: przemieszczenia dyskursu edukacyjnego, Taraźniejszość Człowiek - Edukacja, 2001.

Śliwerski B., Diagnoza uspołecznienia publicznego szkolnictwa III RP. W gorsecie centralizmu, Oficyna Wydawnicza Impuls, Kraków 2013.

Śliwerski B., Meblowanie szkolnej demokracji, Wolters Kluwer, Warszawa 2017.

Wheeler C.M., Pokonaj stres. 10 sprawdzonych metod, Gdańskie Wydawnictwo Psychologiczne, Gdańsk 2016.

Wtadza. Pokusy i zagrożenia, red. A.Y. Lee-Chai, J.A. Bargh, Gdańskie Wydawnictwo Psychologiczne, Gdańsk 2009. 